\author{
JURNAL PENJAMINAN MUTU \\ LEMBAGA PENJAMINAN MUTU \\ INSTITUT HINDU DHARMA NEGERI
}

DENPASAR
Volume 5 Nomor 1 Februari 2019

ISSN : 2407-912X (Cetak)

ISSN : 2548-3110 (Online)

http://ejournal.ihdn.ac.id/index.php/JPM

\title{
PENGUASAAN MATERI MEDIA PEMBELAJARAN DALAM UPAYA MENYIAPKAN GURU YANG MAMPU MENYELENGGARAKAN PEMBELAJARAN YANG MENDIDIK
}

\author{
Oleh \\ Emma Himayaturohmah \\ Balai Diklat Keagamaan Bandung \\ emmahimayaturohmah@gmail.com
}

diterima 8 Pebruari 2019, direvisi 25 Februari 2019, diterbitkan 28 Februari 2019

\begin{abstract}
The problem of this study is the low mastery of computer-based learning media or information technology for Madrasah Ibtidaiyah teachers. The low mastery capacity of learning media directly influences the low competency in conducting educational education. Current curriculum demands teachers are required to master the use of technology in classroom learning. The purpose of this study was to determine the mastery of learning media materials and competencies in conducting educational learning. This research is a field research quantitative descriptive approach. The subjects in this study were Information and Communication Technology-Based Learning Media Training Participants for Teachers of Islamic Education in Kuningan District, West Java Province. Data collection techniques were carried out using questionnaires, observation, interviews and documentation studies. The results showed that mastery of learning media material had an average value of 85.86 which was categorized as good. While mastery of competency in organizing learning that educates has an average value of 80.5 which means it has a good category.
\end{abstract}

\section{Keywords: Teacher, Learning Media, Technology, Competence}

\section{PENDAHULUAN}

Pembelajaran adalah interaksi antara pendidik dan peserta didik dengan sumber belajar pada sebuah lingkungan belajar tertentu. Proses pembelajaran adalah sebuah interaksi timbal balik yang terjadi ketika sebuah pembelajaran berlangsung, selama kurun waktu tertentu. Situasi yang tercipta dalam sebuah proses pembelajaran, sepenuhnya dalam wilayah kekuasaan guru. Guru yang memegang peranan aktif mau dibawa ke mana siswa-siswa dan proses belajar mengajar itu

Guru memiliki tuntutan menyelenggarakan pembelajaran sesuai regulasi yang sudah ditetapkan oleh 
pemerintah. Hal ini dilakukan agar tujuan pembelajaran dapat tercapai dengan baik, sesuai dengan indikator yang telah ditetapkan oleh guru sendiri dalam Rancangan Persiapan Perencanaan Pembelajaran RPP). Tujuan dapat tercapai jika proses pembelajaran tercipta sesuai dengan tahapan metode yang digunakan. Proses belajar mengajar akan berjalan baik, jika sejak awal direncanakan dengan baik pula. Faktanya, di lapangan masih banyak guru yang belum menyiapkan rencana pembelajaran dengan semestinya.

Efek dari persiapan yang kurang baik, proses belajar tidak melibatkan siswa secara utuh. Sehingga, siswa tidak merasa perlu dan tertarik dengan materi pelajaran sekaligus tidak berminat mengikuti pembelajaran. Hal ini banyak sekali faktor yang mempengaruhinya. Bisa karena metode yang diterapkan, media yang digunakan, cara berkomunikasi guru, atau kondisi kelas yang tidak kondusif.

Selain karena faktor-faktor tersebut di atas, faktor pemahaman guru tentang kondisi jiwa dan usia anak didik juga memegang peranan penting dalam menciptakan proses pembelajaran yang meningkatkan minat peserta didik. Misalnya, pembelajaran matematika di kelas 3 SD/MI akan berbeda dengan pembelajaran matematika di kelas 6 . Usia yang berbeda, memiliki tuntutan dan karakteristik yang berbeda pula. Ini harus menjadi bahan pertimbangan guru dalam menentukan persiapan dan pelaksanaan pembelajaran

Pembelajaran yang efektif tercipta jika siswa merasa senang dan terlibat langsung di dalamnya. Siswa akan sangat antusias bila belajar dihadapkan pada situasi-situasi yang membuat mereka penasaran sekaligus tertantang. Sehingga, guru harus bisa menyiapkan berbagai alat dan media pembelajaran yang bisa memacu rasa penasaran siswa selama pembelajaran berlangsung.

Pembelajaran menyenangkan memang membutuhkan banyak dukungan. Penguasaan metode pembelajaran dan media pembelajaran, menjadi dua hal yang paling urgen. Sebab, keduanya menjadi modal utama bagi terciptanya kelas yang menyenangkan. Pengemasan materi yang menarik, menjadi awal dari keberhasilan proses interaksi edukatif yang efektif. Di Sisi lain, untuk kasus guru Sekolah Dasar, penggunaan media pembelajaran masih belum sepenuhnya dikuasai. Terutama media pembelajaran berbasis komputer dan TIK.

Terdapat banyak manfaat dari penggunaan media pembelajaran dalam proses belajar mengajar. Selain membuat siswa merasa senang dan terpacu, juga belajar tentang hal yang baru dari media yang digunakan oleh guru. Apalagi jika guru menggunakan media pembelajaran yang bersifat interaktif.

Media Pembelajaran memegang peranan yang cukup menentukan dalam keberhasilan sebuah proses pembelajaran. Menurut Saud (2009: 66), media pembelajaran merupakan sarana pembelajaran yang digunakan sebagai perantara dalam proses pembelajaran untuk mempertinggi efektivitas dan efisiensi dalam mencapai tujuan pembelajaran. Hal ini menunjukkan bahwa efektivitas dan efisiensi pembelajaran dapat dicapai, salah satunya, dengan penggunaan media pembelajaran.

Jika guru menggunakan media pembelajaran, maka fungsi medianya juga harus dipahami. Menurut Sudjana (1991:134-135), media digunakan bukan sebagai fungsi tambahan, tetapi alat bantu untuk mewujudkan situasi belajar mengajar yang efektif. Selain itu, penggunaannya merupakan bagian yang integral dari keseluruhan situasi belajar mengajar, bukan semata-mata alat hiburan.

Kemampuan guru terhadap penguasaan media pembelajaran akan berimplikasi pada mutu pembelajaran di kelas. Padahal, tuntutan kompetensi guru itu sangat banyak. Setidaknya, guru harus memiliki empat standar kompetensi sesuai Permendikbud nomor 16 tahun 2007. Guru dituntut untuk memiliki sepuluh kemampuan, yaitu: menguasai bahan, mengelola program belajar mengajar, mengelola kelas, penggunaan media atau sumber belajar, menguasai 
landasan-landasan pendidikan, mengelola interaksi-interaksi belajar mengajar, menilai prestasi siswa untuk kepentingan pembelajaran, mengenal fungsi bimbingan dan penyuluhan di sekolah, mengenal dan menyelenggarakan administrasi sekolah, serta memahami prinsip-prinsip dan menafsirkan hasil penelitian pendidikan guna keperluan pengajaran (Depdikbud, 1985). Bahkan, kalau menghitung indikator kompetensi yang harus dimiliki Guru MI, pada Permendikbud 16 tahun 2007 berjumlah 92 indikator. Tetapi, dalam penelitian ini hanya 6 indikator saja, dari kompetensi menyelenggarakan pembelajaran yang mendidik. Kompetensi itu merupakan bagian dari kompetensi pedagogik.

\section{METODE}

Penelitian ini merupakan penelitian lapangan (field reserch) dengan pendekatan deskriptif kuantitatif. Penelitian dilaksanakan pada bulan Maret 2018. Subjek dalam penelitian ini adalah 30 orang peserta Diklat Media Pembelajaran Berbasis Teknologi Informasi dan Komunikasi di Kabupaten
Kuningan Provinsi Jawa Barat. Teknik pengumpulan data dilakukan dengan cara kuisioner, observasi, wawancara, dan dokumentasi. Dalam menguji keabsahan data digunakan teknik triangulasi sumber dan metode.

\section{HASIL DAN PEMBAHASAN}

Penguasaan materi praktik pembuatan media pembelajaran berbasis power point, menggunakan kuesioner yang diisi oleh peserta, serta observasi yang dilakukan oleh peneliti, didapat hasil-hasil yang menunjukan secara rinci penguasaan mereka terhadap materi microsof power point.

Penguasaan Peserta terhadap Menu Pada Microsof Power Poin: Menu Home, Insert, Design, Transition, Animation, Slide Show, dan View. Pada masing-masing menu, terdapat beberapa fungsi. Di bawah ini disajikan data tentang penguasaan materi pada masing-masing fungsi yang ada pada Microsoft power point. Secara rinci, penguasaan materi media pembelajaran berbasis power point, tampak pada baganbagan berikut:

1. Menu Home, terdiri dari fungsi-fungsi: Cut, New Slide, Reset, Delet, Lay Out, Edit Font, Paragrap, Numeric dan Backround

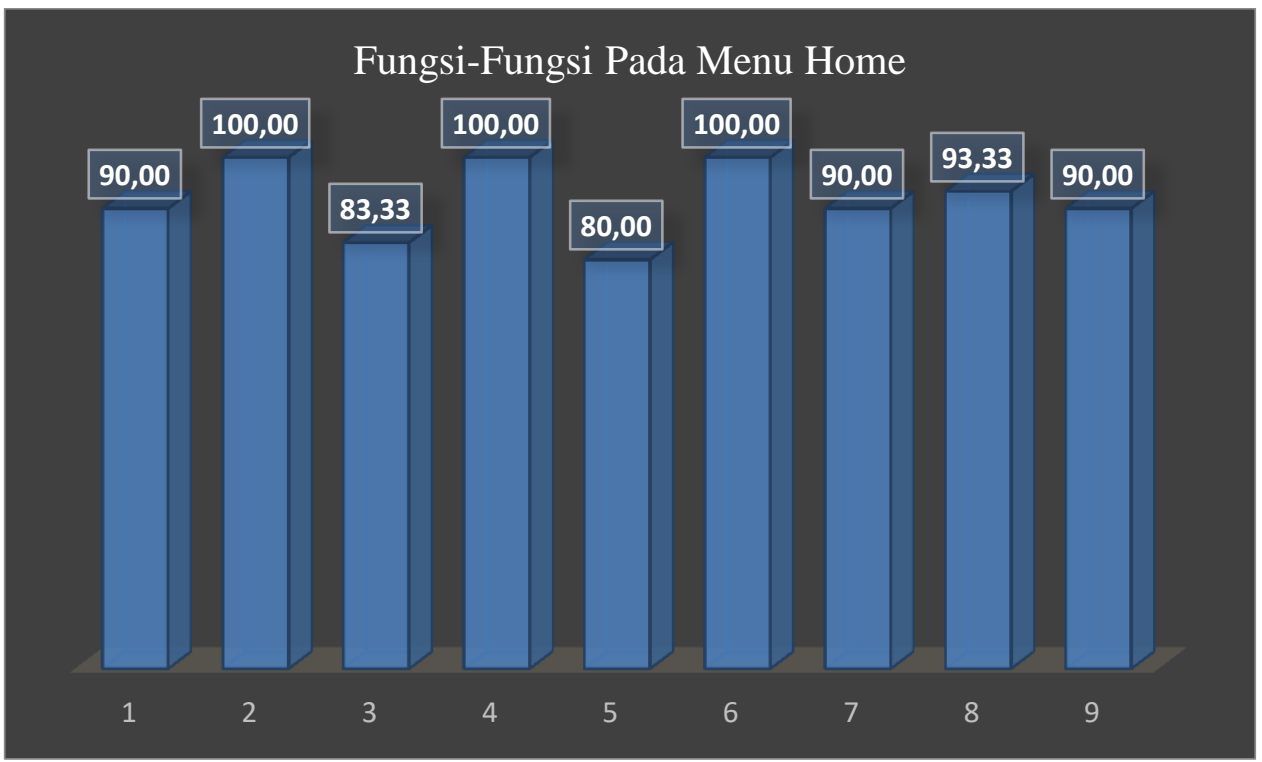

Gambar 1

Penguasaan materi media pembelajaran dalam praktik pembuatan bahan tayang power point pada Home 
2. Menu Insert, terdiri dari fungsi-fungsi: Table, Picture, Clipart, Foto Album, Shapes, Smart Art, Chart, Hyperlink, Text Box Header \& Footer, Word Art, Date \& Time, Symbol, Object, Movie Dan Audio.

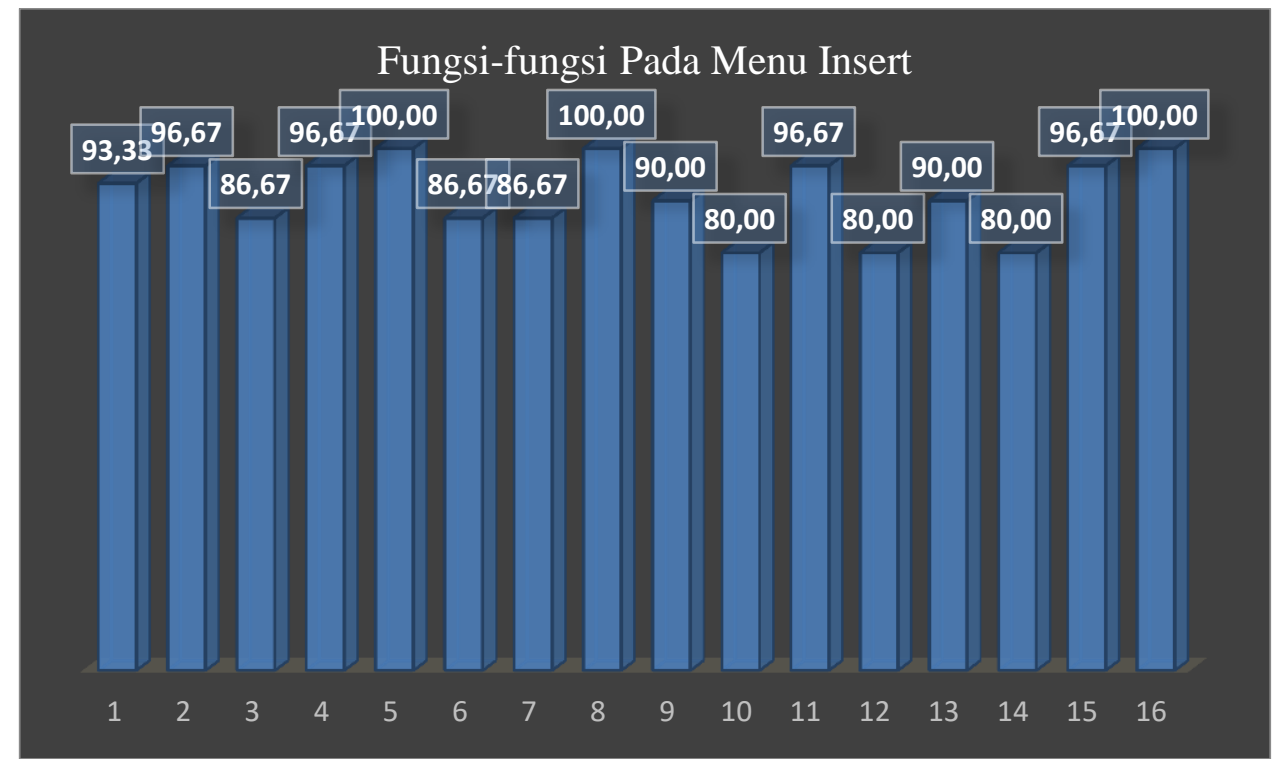

Gambar 2

Penguasaan materi media pembelajaran dalam praktik pembuatan bahan tayang power point pada Insert

3. Menu Design, terdiri atas fungsi-fungsi: Page Setup, Slide Orientation, Themes, Colors, Fonts, Effect Dan Backround Slide.

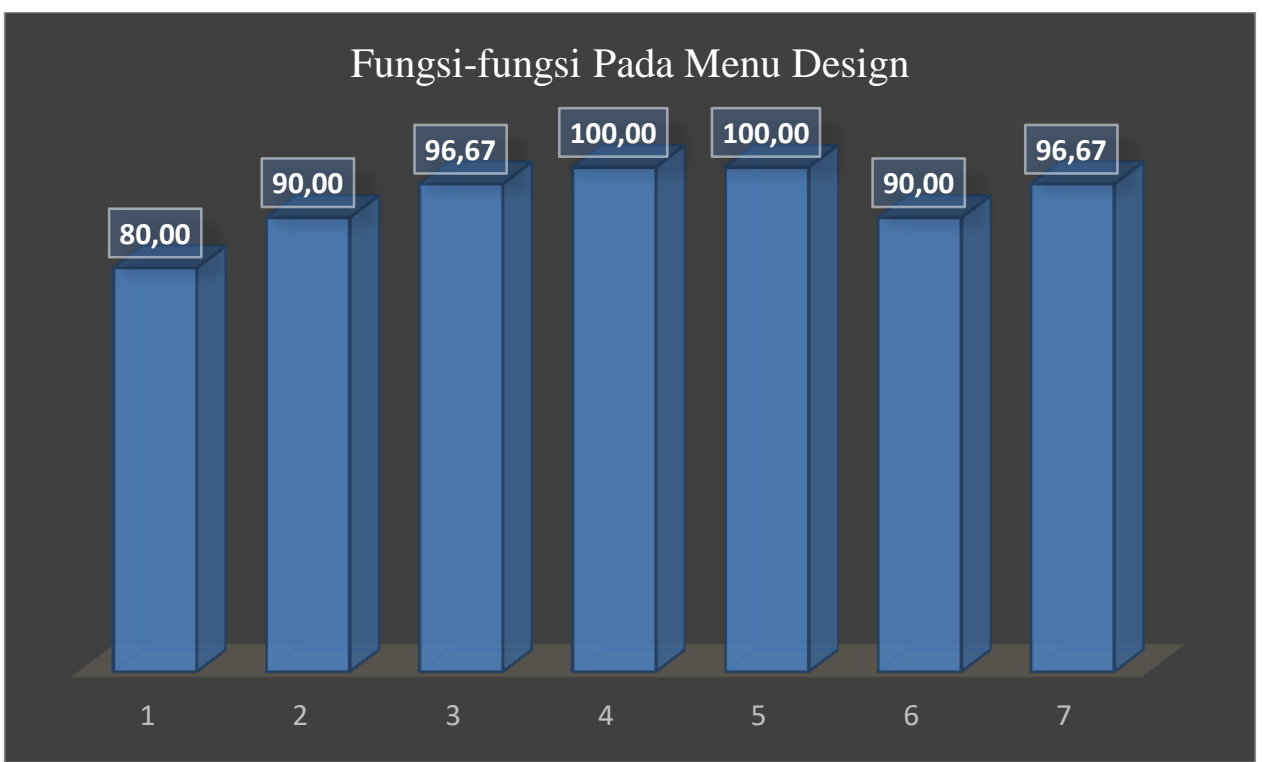

Gambar 3

Penguasaan materi media pembelajaran dalam praktik pembuatan bahan tayang power point pada Design

4. Menu Transition, terdiri atas fungsi-fungsi: preview, transition, effect option, sound, duration, applay to all, dan advance slide. 


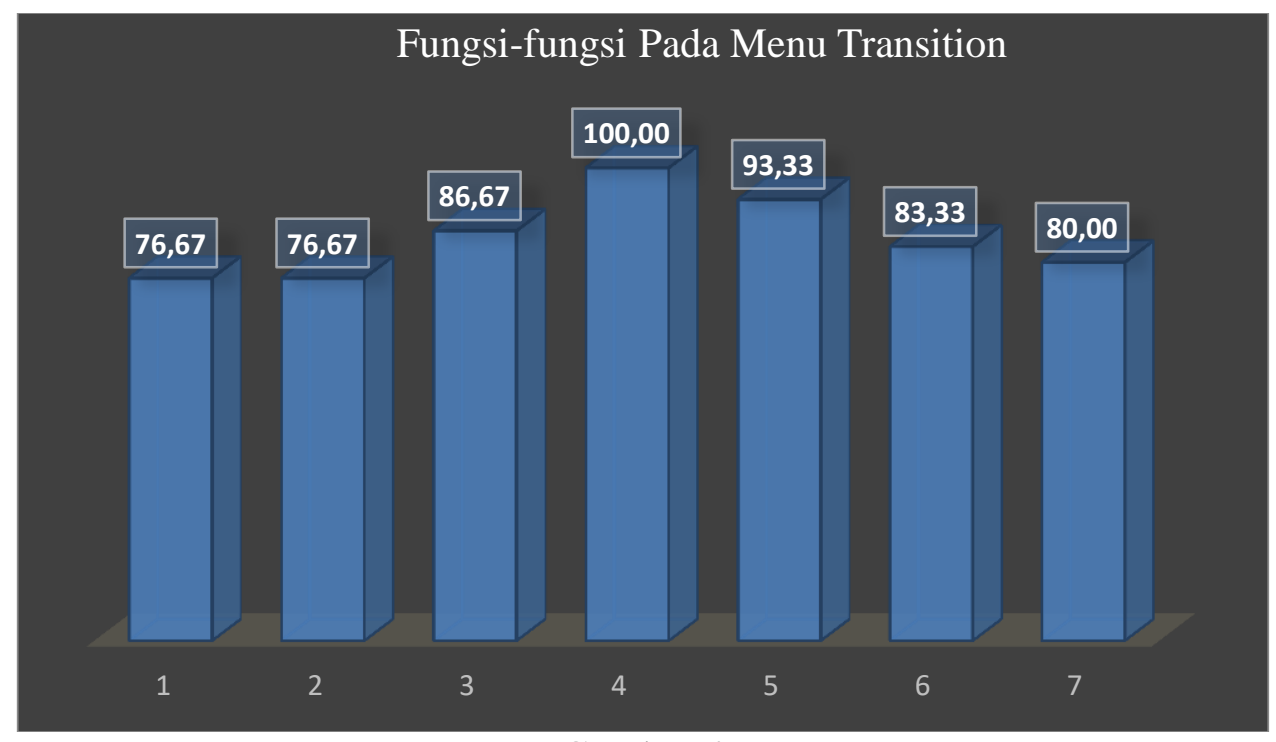

Gambar 4

Penguasaan materi media pembelajaran dalam praktik pembuatan bahan tayang power point pada Transition

5. Menu Animation, terdiri dari fungsi-fungsi: Preview, Macam-Macam Animasi, Add Animation, Animation Pane, Trigger, Animation Painter, Advanced Slide (Start, Dutation, Delay), Dan Reorder.

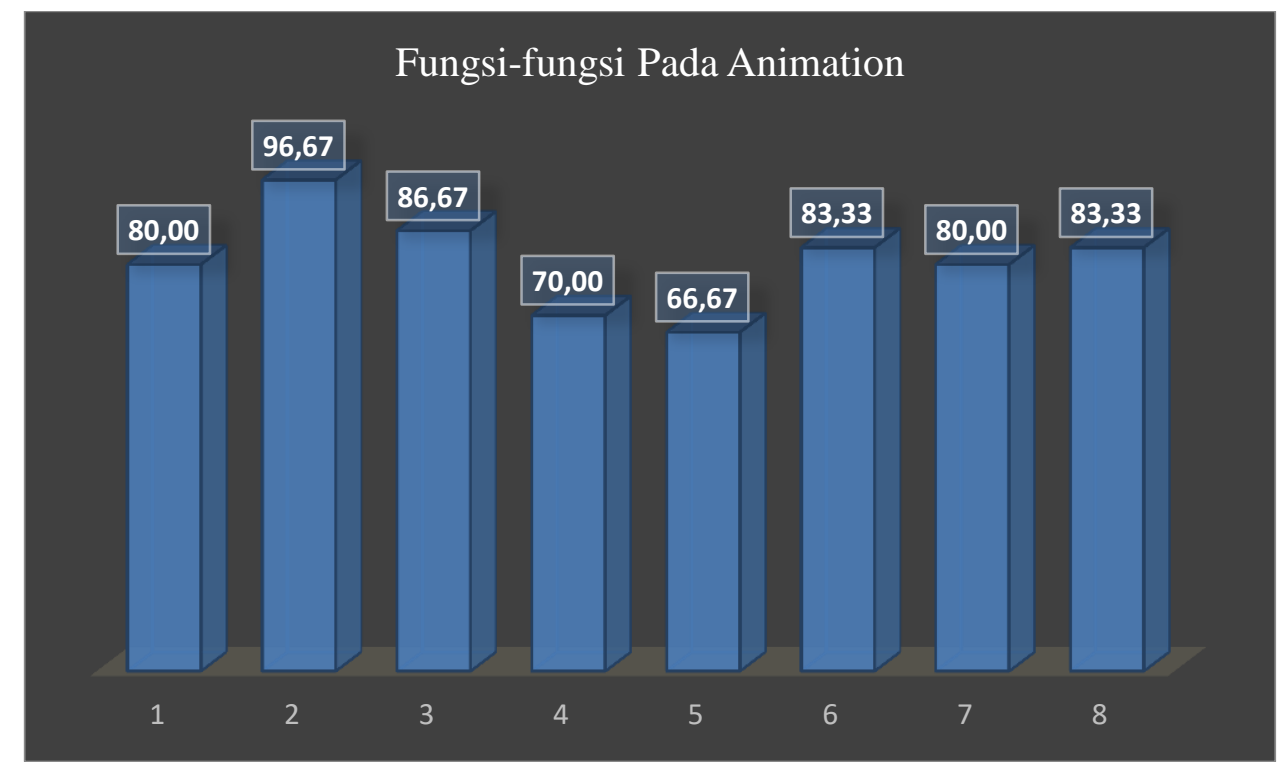

Gambar 5

Penguasaan materi media pembelajaran dalam praktik pembuatan bahan tayang power point pada Insert

6. Menu View terdiri atas fungsi-fungsi: presentation view, show or hide, colors, window dan macros. 


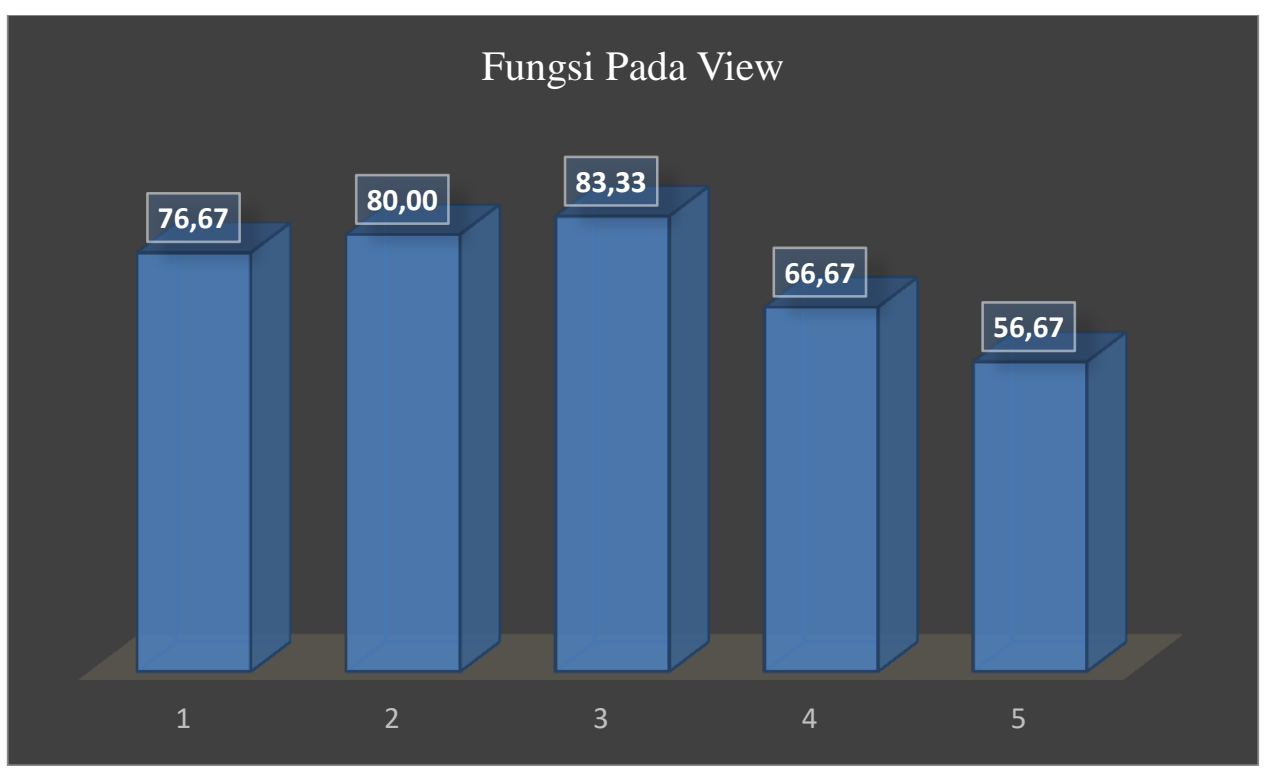

Gambar 6

Penguasaan materi media pembelajaran dalam praktik pembuatan bahan tayang power point pada View

Data keseluruhan rata-rata penguasaan materi power point, akan tampak pada gambar di bawah ini:

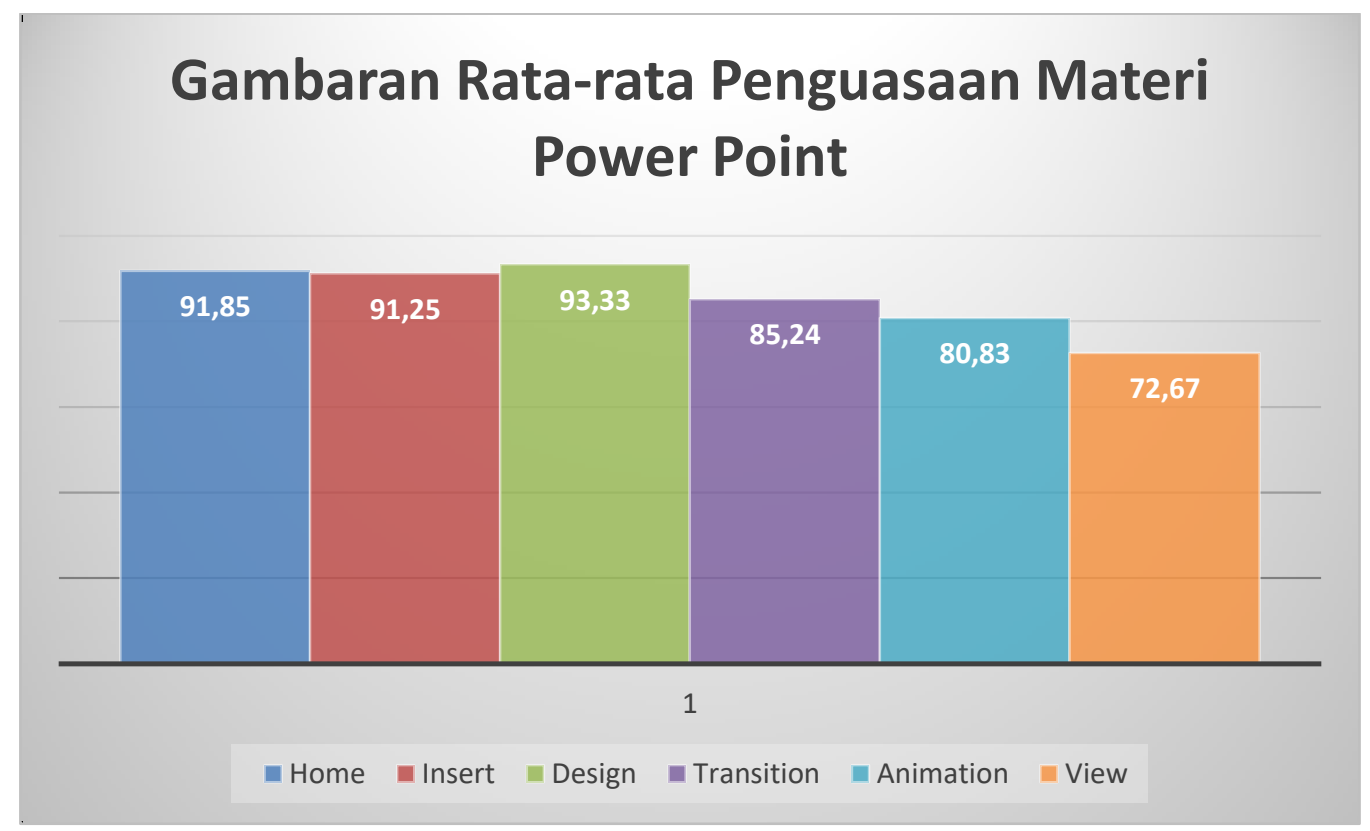

Gambar 7

Rata-rata Penguasaan materi media pembelajaran dalam praktik pembuatan bahan tayang power point

Adapun kemampuan guru dalam yang mendidik, 2) mengembangkan, menyelenggarakan pembelajaran yang komponen-komponen rancangan mendidik, setelah menyelesaikan Diklat pembelajaran, 3) menyusun rancangan Media Pembelajaran adalah kemampuan pembelajaran yang lengkap, baik untuk guru dalam 5 indikator, yaitu: 1) memahami kegiatan di dalam kelas, laboratorium, prinsip-prinsip perancangan pembelajaran maupun lapangan, 4) melaksanakan 
pembelajaran yang mendidik di kelas, di laboratorium, dan di lapangan, 5) menggunakan media pembelajaran sesuai dengan karakteristik peserta didik dan lima mata pelajaran SD/MI untuk mencapai tujuan pembelajaran secara utuh, dan 6) mengambil keputusan transaksional dalam lima mata pelajaran SD/MI sesuai dengan situasi yang berkembang.

Berdasarkan kuesioner dan wawancara, diperoleh gambaran data sebagai berikut:

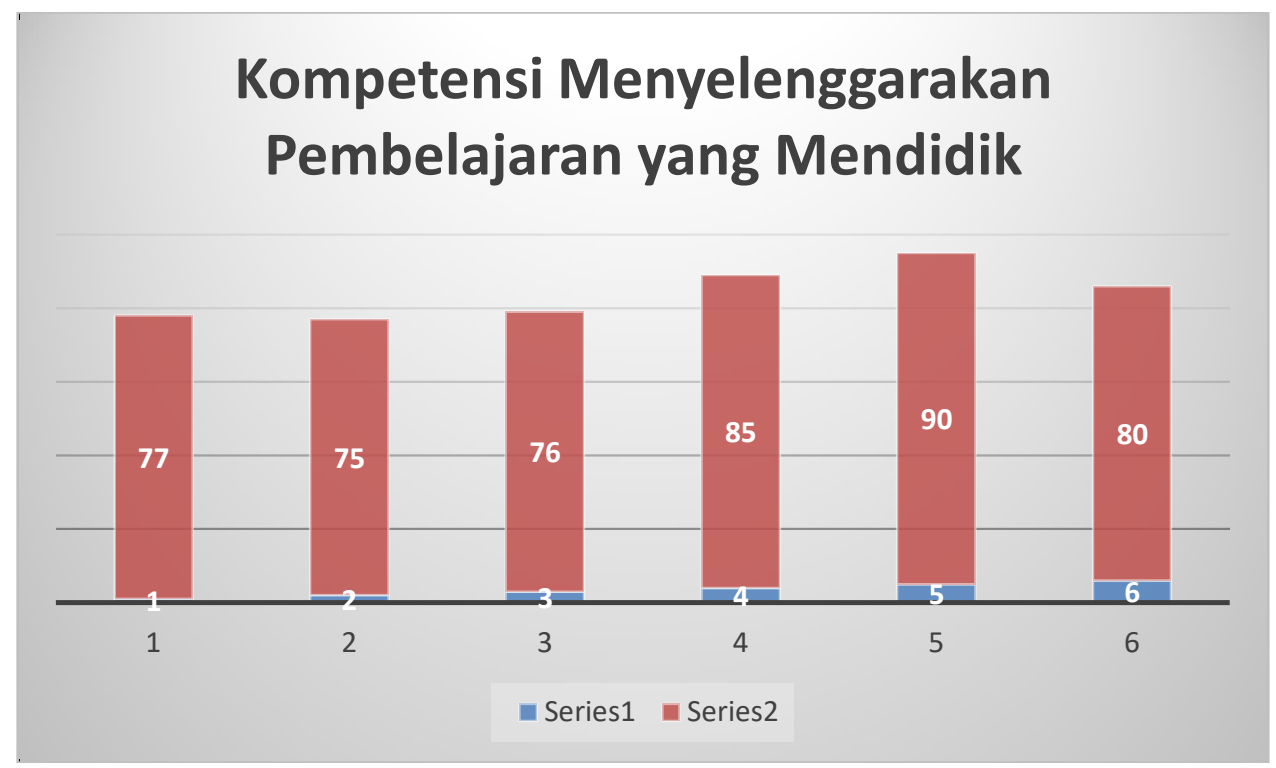

Gambar 8

Gambaran kemampuan peserta dalam menyelenggarakan pembelajaran yang mendidik

Data di atas merupakan data lapangan yang diperoleh ketika proses pembelajaran Diklat Media Pembelajaran yang dilaksanakan di Kabupaten Kuningan Jawa Barat. Peserta pada Diklat ini adalah guruguru Madrasah Ibtidaiyah (setingkat Sekolah Dasar). Mereka menjadi dapat menjadi peserta Diklat ini, dengan asumsi sudah memenuhi persyaratan yang ditetapkan oleh panitia, yaitu mampu mengoperasikan komputer tingkat dasar.

Diklat Media Pembelajaran ini bertujuan memberi keterampilan membuat media pembelajaran (bahan tayang power point) untuk kepentingan mengajar di kelas. Peserta dituntut untuk mampu membuat bahan tayang tersebut, sebagai hasil belajar mereka selama diklat. Hal ini senada dengan pendapat Djamarah dkk. (2006:11) bahwa belajar adalah proses perubahan perilaku berkat pengalaman dan latihan. Pada intinya, hakikat belajar adalah perubahan. Sebelum guru mampu membuat siswanya berubah, guru dulu yang harus memulai perubahan itu. Kelas Diklat menjadi semacam tempat merubah pemahaman, pengetahuan dan keterampilan para guru.

Ketika guru berada di kelas, maka guru semetinya sudah siap melakukan proses belajar mengajar. Artinya, perencanaan pembelajarannya sudah matang. Semua komponen pembelajaran juga telah disiapkan oleh guru sebelum memulai pembelajaran. Komponen belajar mengajar meliputi: bahan pelajaran, kegiatan belajar mengajar, metode, alat dan sumber serta evaluasi (Djamarah dkk, 2006: 41). Itu berarti, bukan hanya bahan pelajaran saja yang harus disiapkan guru sebelum masuk kelas, tetapi komponen lain pun sudah harus siap sebelum masuk kelas, termasuk di dalamnya media pembelajaran yang akan digunakan.

Seorang guru akan sangat senang jika siswa dapat mengikuti pembelajarn di kelas dengan sangat antusias. Hal ini bisa terjadi jika interaksi yang terjadi bersifat timbal 
balik. Artinya, siswa dan guru saling membutuhkan, saling terlibat langsung dan saling memberi. Kenyataannya, banyak sekali bahan pelajaran yang bersifar verbal, sulit dibawa ke kelas, ukurannya sangat kecil, atau bahkan sangat besar. Hal ini bisa diselesaikan dengan menggunakan media pembelajaran. Di sinilah pentingnya media pembelajaran dalam proses pembelajaran. Hal ini sesuai pendapat dari Bahri, bahwa media pembelajaran memiliki arti yang cukup penting, yaitu bisa menjadi perantara bagi penjelas bahan pelajaran yang disampaikan guru (Djamarah dkk, 2006:120).
Pada sisi inilah dipandang pentingnya guru menggunakan media pembelajaran untuk memperjelas materi yang terbatas ruang dan waktu (Sudarsana, 2018). Masalahnya, apakah semua guru mampu membuat media pembelajaran yang digunakan untuk mempercepat pencapaian tujuan? Apalagi media pembelajaran berbasis komputer atau berbasis TIK bagi guru-guru tingkat Sekolah Dasar. Sehingga, banyak di antara para guru yang mengajar apa adanya saja. Tanpa media pembelajaran yang memadai. Sehingga, pembelajaran berjalan nyaris tanpa semangat dan kurang greget dalam prosesnya.

Rohani (1997:5) menggambarkan proses pembelajaran di sekolah yang dilakukan guru, kaitannya dengan penggunaan media pembelajaran, seperti gambar di bawah ini:

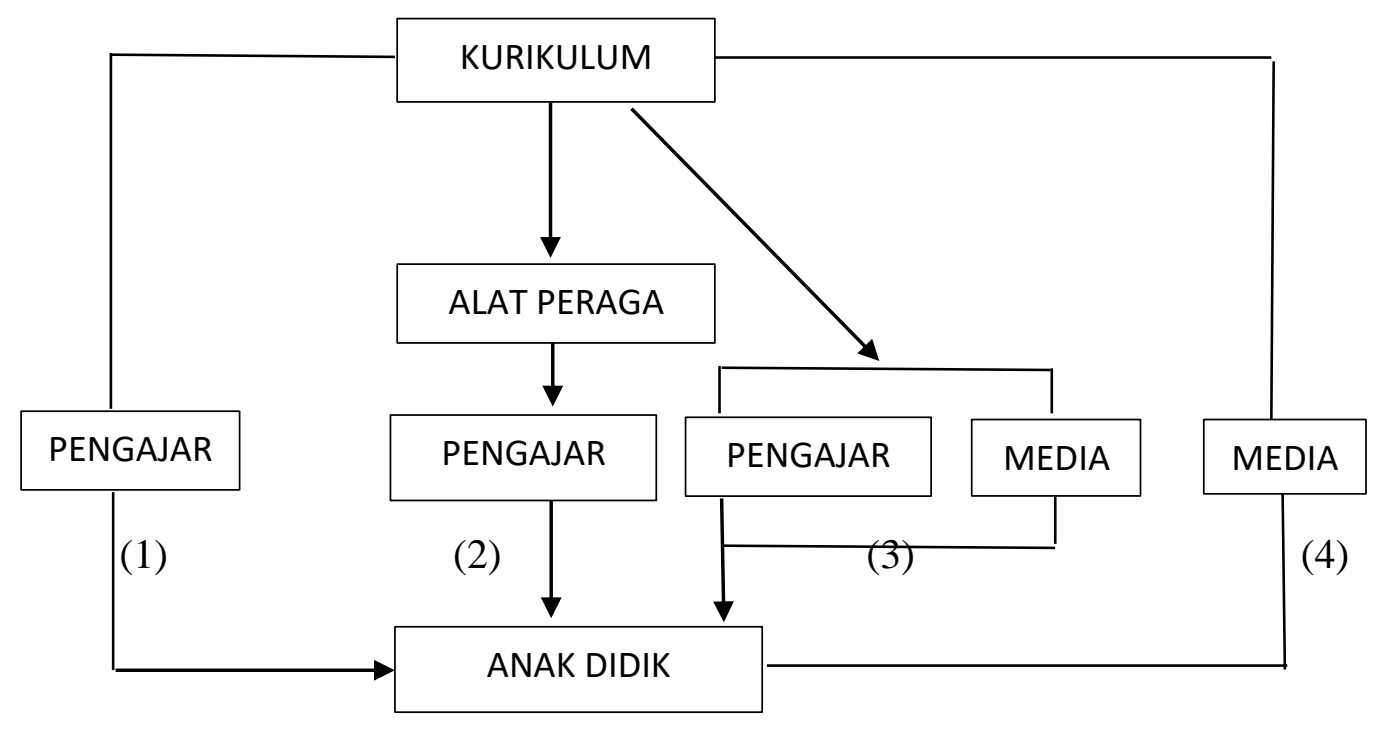

Gambar 9

Pola interaksi sumber belajar dengan siswa dalam pembelajaran

Gambar di atas menunjukkan 4 pola dasar proses pembelajaran. Pola pertama, sumber belajar peserta didik hanya berupa orang saja, yaitu guru. Pada pola ini guru memegang kendali yang penuh atas terjadinya kegiatan belajar mengajar. Pola kedua, sumber belajar peserta didik berupa orang (guru) dibantu bahan atau sumber lain. Guru memegang kendali, tetapi tidak mutlak. Sumber lain berfungsi sebagai alat bantu atau alat peraga. Pola ketiga, sumber belajar peserta didik berupa orang dan sumber lain berdasarkan pembagian tanggung jawab.
Sumber lain itu merupakan bagian integral dari keseluruhan kegiatan belajar. Sumber lain itu disebut media. Pola keempat, adalah pola di mana sumber belajar peserta didik hanya dari sumber bukan manusia (media).

Pola-pola interaksi ini penting difahami oleh guru dalam kaitan penggunaan media pembelajaran di kelas. Pola pertama dan kedua, tentu tidak akan digunakan oleh guru. Karena, pembelajaran pola pertama dan kedua, sumber belajar siswa tunggal, hanya guru saja, atau media saja. Itu berarti, guru bisa menggunakan media sebagai alat bantu 
pembelajaran atau media sebagai bagian tak terpisahkan dalam proses pembelajaran. Kedua pola tersebut, mengharuskan guru menguasai pembuatan dan penggunaan media yang akan digunakan dalam proses pembelajaran.

Pada tulisan ini, diberikan gambaran cukup jelas bagaimana gambaran penguasaan guru, yang notabene adalah peserta diklat media pembelajaran, terhadap pembuatan media pembelajaran berbasis power point, yang akan mereka gunakan di kelas. Pada gambar 1 sampai 7 tampak nilai rata-rata penguasaan materi guru terhadap menumenu yang ada pada Microsoft power point.

Penilaian penguasaan materi berdasarkan Kurikulum Pusdiklat tahun 2017, berdasarkan Surat Keputusan Kepala Badan Litbang dan Diklat Kementerian Agama nomor 62 tahun 2017 tentang Kurikulum Pendidikan dan pelatihan Tenaga Teknis Pendidikan dan Keagamaan tahun 2017 beserta lampirannya, menjelaskan kriteria penilaian penguasaan materi adalah: 0-70 kriteria kurang, 71-80 kriteria cukup, 81-90 kriteria baik, dan 91-100 kriteria sangat baik.

Pada gambar 1 tampak penguasaan praktik membuat bahan tayang power point pada menu home, secara umum peserta sudah mampu melakukannya dengan baik. Hanya, pada fungsi Lay out, memiliki nilai rata-rata terrendah, dengan nilai 80 . Itu menunjukkan penguasaan terrendah pencapaian nilai baik pada Diklat Media Pembelajaran. Hal ini menunjukkan bahwa pada fungsi ini mereka belum begitu menguasai. Jika dilihat secara fungsional, memang fungsi Lay out pada menu Home ini jarang digunakan untuk pembuatan bahan tayang tahap awal.

Pada gambar 2, tampak jelas bahwa penguasaan menu Insert sudah cukup bagus. Hanya ada 3 fungsi yang nilai rata-ratanya 80 , yaitu header \& footer, date \& time serta object. Hal ini memang bisa difahami, selain memang juga tidak secara detail dijelaskan oleh pengajar (Widyaiswara) juga ketiga fungsi ini jarang digunakan pada bahan tayang yang dibuat oleh guru sekolah tingkat dasar (SD dan MI). Sementara, fungsi-fungsi lain, seperti shapes, hyperlink dan sound, bisa dikuasai dengan sempurna oleh peserta. Hal ini terjadi, karena, semua peserta menggunakan fungsi-fungsi tersebut pada slide mereka. Sehingga, tayangan yang mereka miliki, memiliki suara dan terkoneksi dengan web yang mereka inginkan.

Pada gambar 3, menu Design hampir bisa dikuasai peserta sepenuhnya. Hanya fungsi page set up yang memiliki nilai 80 . Hal ini menjadi gambaran yang jelas bahwa peserta umumnya belum menguasai, atau memang belum menggunakan fungsi ini dalam mengedit slide-slide yang dibuat saat praktik.

Pada gambar 4 menu Transition tampak memiliki beberapa nilai rata-rata yang di bawah 80, yaitu untuk fungsi preview dan transition to this slide. Hal ini memang dapat difahami, karena kedua fungsi tersebut sudah mereka lakukan langsung tanpa menekan terlebih dahulu fungsi tersebut. Jadi, jika dilihat dari sisi praktik, mereka sudah menggunakannya. Ketika mereka memilih salah satu fungsi transition, secara otomatis mereka sudah menggunakan fungsi tersebut. Begitu juga fungsi preview.

Pada gambar 5 tentang penguasaan peserta pada menu Animation, tampak poin 4 dan 5, yaitu animation pane dan trigger, memiliki rata-rata penguasaan di bawah 80 . Hal ini memang bisa disebut wajar, karena pada praktiknya, ketika mereka membuat slide, kedua fungsi ini tidak begitu banyak dibahas, dan tidak juga semua faham fungsinya. Tapi, beberapa diantara peserta sudah bisa menggunakannya, meski tanpa dipandu oleh pengajar.

Pada gambar 6 tampak penguasaan peserta terhadap menu View, tampak hanya 2 fungsi yang bisa difahami oleh peserta secara baik. Fungsi-fungsi lainnya memiliki nilai rata-rata di bawah 80. Apalagi fungsi macross yang mencapai angka rata-rata 56,67. Hal ini memang memperlihatkan penguasaan peserta terhadap fungsi View ini masih rendah. Fungsi view pada slide memang tidak terlalu sering digunakan, tidak seperti pada fungsi-fungsi lain pada menu 
selain view. Pada kegiatan praktik pun, fungsi view ini hanya dibahas sekilas saja.

Secara keseluruhan, penguasaan materi Microsoft power point bagi guru Madrasah Ibtidaiyah di Kabupaten Kuningan, tampak pada gambar 7. Secara berturut-turut, ratarata penguasaan materi microsof power point pada menu Home (91,85 kategori sangat baik), Insert (91,25 kategori sangat baik), Design (93,33 kategori sangat baik), Transition (85,24 kategori baik), Animation (80,83 kategori baik), dan View (72,67 kategori cukup). Jika dirata-ratakan secara keseluruhan, maka nilainya adalah 85,86. Ini menunjukkan secara rata-rata, kemampuan penguasaan peserta terhadap Microsoft power point adalah berkategori Baik.

Setelah guru memiliki kemampuan baik dalam menyusun media pembelajaran, langkah berikutnya, guru harus faham benar cara menggunakan media pembelajaran itu. Tidak setiap materi bisa menggunakan media yang sama. Guru harus memperhatikan prinsip-prinsip penggunaan media pembelajaran. Sudjana (1991:127) menjelaskan prinsip-prinsip penggunaan media pembelajaran adalah: menentukan jenis media dengan tepat, menetapkan dan memperhitungkan subjek dengan tepat, menyajikan media dengan tepat, serta menempatkan atau memperlihatkan media pada waktu, tempat dan situasi yang tepat.

Setelah guru memperhitungkan prinsip-prinsip penggunaan media, tujuan penggunaan media pembelajaran juga harus tepat sesuai dengan tujuan yang ingin dicapai. Artinya, tujuan penggunaan media pembelajaran harus menyesuaikan dengan tujuan pembelajaran yang ingin dicapai. Tidak boleh masing-masing, tidak boleh berbeda. Dalam pandangan Saud (2009:67), guru harus mempertimbangkan tujuan penggunaan media pembelajaran, ketika menggunakan media di kelas, yaitu: untuk memperjelas penyajian pesan agar tidak verbalistis, mengatasi ruang, waktu dan daya indera, memperlancar proses pembelajaran, menimbulkan gairah belajar, memberi kesempatan kepada siswa untuk berinteraksi langsung dengan lingkungan dan kenyataan, serta memberi kesempatan kepada siswa untuk belajar secara mandiri sesuai dengan kemampuan dan minatnya. Jika tujuan itu tidak ada, maka tidak perlu guru menggunakan media pembelajaran tersebut.

Jika guru sudah melakukan perencanaan pembelajaran dengan baik, termasuk di dalamnya penyiapan media pembelajaran, diharapkan guru menjadi lebih baik dan mutu pembelajaran di kelas akan meningkat. Selain itu, guru akan memiliki standar kompetensi pedagogik, khususnya kompetensi menyelenggarakan pembelajaran yang mendidik. Pada Permendiknas 16 tahun 2007, indikator kompetensi menyelenggarakan pembelajaran yang mendidik terdiri dari: 1) memahami prinsipprinsip perancangan pembelajaran yang mendidik, 2) mengembangkan, komponenkomponen rancangan pembelajaran, 3) menyusun rancangan pembelajaran yang lengkap, baik untuk kegiatan di dalam kelas, laboratorium, maupun lapangan, 4) melaksanakan pembelajaran yang mendidik di kelas, di laboratorium, dan di lapangan, 5) menggunakan media pembelajaran sesuai dengan karakteristik peserta didik dan lima mata pelajaran SD/MI untuk mencapai tujuan pembelajaran secara utuh, dan 6) mengambil keputusan transaksional dalam lima mata pelajaran SD/MI sesuai dengan situasi yang berkembang.

Pada gambar 8 tampak gambaran yang jelas tentang tanggapan peserta terhadap posisi mereka setelah selesai materi dalam menyelenggarakan pembelajaran yang mendidik. Indikator pertama memiliki nilai rata-rata 77 , indikator kedua 75 , indikator ketiga 76, indikator keempat 85, indikator kelima 90 dan indikator keenam 80. Jika dijumlahkan dan dirata-ratakan, maka kemampuan guru dalam menyelenggarakan pembelajaran yang mendidik memiliki nilai 80,5, kategori baik. Itu artinya, kemampuan guru dalam menguasai materi media pembelajaran, memiliki efek positif terhadap kemampuan guru dalam menyelenggarakan pembelajaran yang mendidik.

Jika melihat hubungan keduanya, kemampuan peserta dalam menguasai media 
pembelajaran dengan kemampuan menyelenggarakan pembelajaran yang mendidik sama-sama memiliki kategori baik. Apalagi untuk indikator kelima dalam menyelenggarakan pembelajaran yang mendidik, yaitu menggunakan media pembelajaran sesuai dengan karakteristik peserta didik dan lima mata pelajaran SD/MI untuk mencapai tujuan pembelajaran secara utuh, memiliki nilai paling besar (90) dari seluruh indikator. Itu menunjukkan bahwa jika guru memiliki kemampuan dalam membuat media pembelajaran, maka secara otomatis indikator ke-5 akan tercapai dengan baik.

Adapun pada indikator pertama sampai ketiga dari menyelenggarakan pembelajaran yang mendidik, yang itu merupakan perencanaan pembelajaran, menunjukkan kategori cukup. Itu berarti guru-guru masih memerlukan pelatihan yang berhubungan dengan perencanaan pembelajaran, misalnya Diklat Rencana Pelaksanaan Pembelajaran (RPP).

Perencanaan pembelajaran memang sangat terkait erat dengan posisi dan peran guru yang sentral dalam pembelajaran, yaitu sebagai Peranan guru menurut korektor, inspiratory, informatory, organisator, motivator, inisiator, fasilitator, pembimbing, demonstrator, pengelola kelas, mediator, supervisor, dan evaluator. (Djamarah,
2006:46). Sehingga, semua hal terkait proses pembelajarn, yang itu adalah tanggung jawab guru dalam melaksanakan peran-peran guru di atas, harus dipersiapkan sebaik-baiknya.

Pada praktiknya di lapangan, guru juga harus tetap menghitung nilai-nilai praktis dari penggunaan media pembelajaran. Sudirman, N dkk (1991), menggarisbawahi nilai-nilai praktis dari penggunaan media pembelajaran, yaitu: meletakkan dasar-dasar yang konkret dari konsep yang abstrak untuk mengurangi verbalisme, menampilkan obyek yang tidak memungkinkan dibawa ke dalam kelas, memperlambat gerakan yang terlalu cepat, dan mempercepat gerakan yang terlalu lambat, menyamakan pemahaman siswa terhadap suatu obyek, membangkitkan motivasi belajar siswa, memungkinkan siswa berinteraksi langsung dengan lingkungannya, bahan pelajaran dapat diulang atau digunakan kembali sesuai kebutuhan, memungkinkan menampilkan obyek yang langka, seperti gerhana matahari total atau hewan yang hidup di kutub, menampilkan obyek-obyek yang sulit diamati.

Guru menggunakan semua media yang bisa membantu siswa memahami materi, agar pencapaian tujuan lebih cepat tercapai. Waktu lebih efektif dan efisien. Sehingga terjadilah yang disebut pengajaran yang efektif. Sederhana saja rumus pengajaran efektif menurut Suryobroto (2002:12):

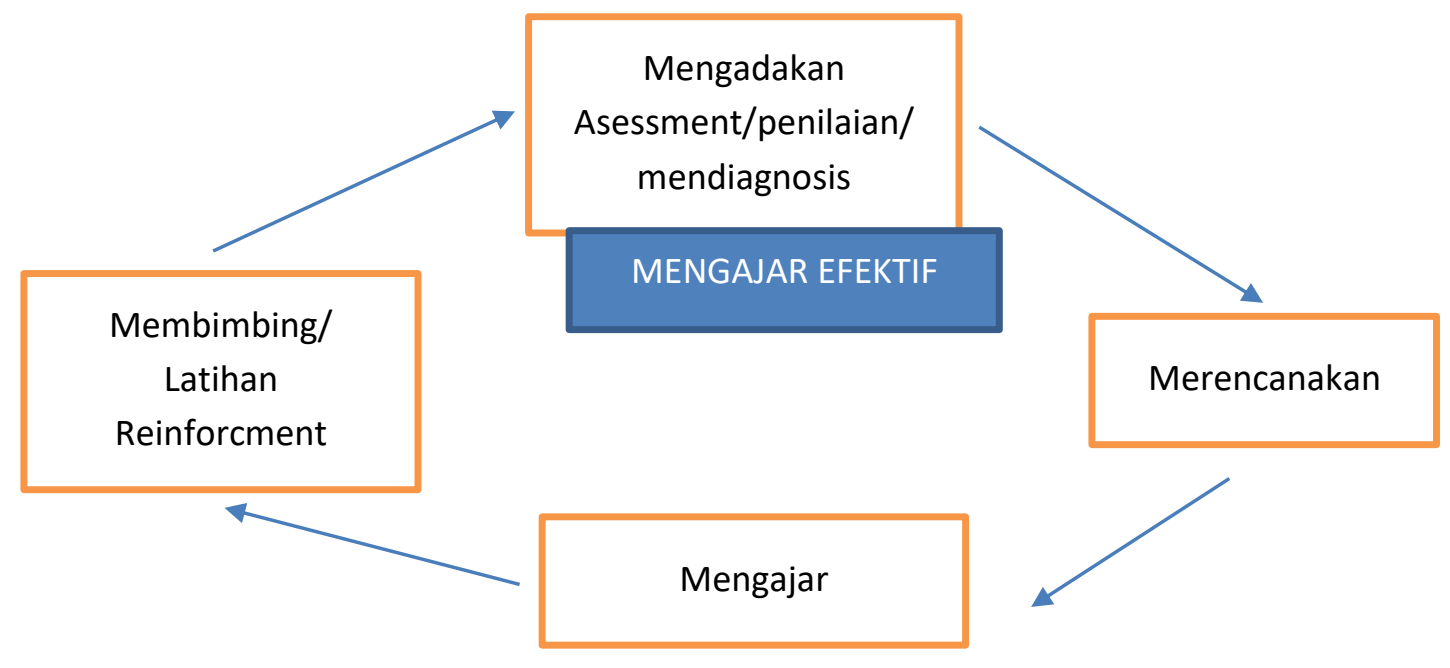

Gambar 10

Aktivitas guru dalam menciptakan pengajaran yang efektif 
Pengajaran efektif itu yang diselenggarakan berdasarkan rencana yang sudah ditetapkan. Rencana pembelajaran dibuat berdasarkan diagnosis atau penilaian sebelumnya, terhadap kemampuan siswa. Sehingga, pembelajaran tidak sia-sia, dan lebih efisien dalam mencapai tujuan pembelajaran. Tidak terlewat juga, pembimbingan oleh guru serta latihan-latihan yang dilakukan oleh siswa, yang terus menerus, dan berulang-ulang, maka kompetensi yang dimiliki siswa akan relatif permanen.

Pengajaran yang efektif harus ditunjang dengan pengelolaan kelas yang efektif pula. Menurut Tung (2015:391-392), mengelola aktivitas kelas secara efektif dapat dilakukan dengan cara, yaitu: memerhatikan dan mengikuti perkembangan keterlibatan siswa, mengatasi situasi tumpang tindih secara efektif, menjaga kelancaran kontinuitas pelajaran, serta melibatkan siswa ke dalam berbagai aktivitas yang menantang.

Jika guru telah mampu melakukan pengajaran yang efektif dan pengelolaan aktivitas kelas yang efektif, maka jadilah guru itu guru yang efekti. Guru efektif, menurut Nasution (1989:110), memiliki ciriciri ini: memulai dan mengakhiri pelajaran tepat waktu, berada terus di dalam kelas dan menggunakan waktunya untuk membimbing siswa, menyambungkan materi sebelumnya ketika memulai pembelajaran, menjelaskan tujuan pembelajaran, menyajikan pelajaran dengan langkah-langkah yang sesuai, memberikan latihan praktis yang mengaktifkan semua siswa, memberi bantuan kepada siswa, bersedia mengulang pembelajaran bila siswa memerlukannya, memberi umpan balik, mengadakan pengulangan secara teratur dan melakukan evaluasi.

\section{KESIMPULAN}

Berdasarkan paparan di atas dapat disimpulkan bahwa penguasaan materi media pembelajaran bagi guru Madrasah Ibtidaiyah berkategori baik. Hal itu menujukkan bahwa proses pembelajaran selama Diklat berjalan dengan baik, sehingga penguasaan materi praktik membuat media pembelajaran Microsoft power point memiliki rata-rata 85,86 berktegori baik. Adapun rata-rata untuk kemampuan guru dalam kompetensi menyelenggarakan pembelajaran yang mendidik 80,50 berkategori baik. Indikator perencanaan pembelajaran memiliki kategori cukup. Sehingga, bisa dikatakan, jika penguasaan kompetensi penyusunan bahan ajar berpengaruh terhadap penguasaan kompetensi penyelenggaraan pembelajaran yang mendidik bagi guru. Berdasarkan kesimpulan itu, direkomondasikan agar peserta mengikuti Diklat perencanaan pembelajaran, agar kompetensi menyelenggarakan pembelajaran yang mendidik dengan indikator pembelajaran meningkat.

\section{Daftar Pustaka}

Bahri Djamarah, Syaiful, dkk. 2006. Strategi Belajar Mengajar. Jakarta: Rineka Cipta.

Bahri Djamarah, Syaiful, dkk. 2010. Guru dan Anak Didik dalam Interaksi Edukatif. Jakarta: Rineka Cipta

Depdikbud. 1985. Buku Petunjuk Pelaksanaan Proses Belajar Mengajar. Jakarta: Dikmenum.

Nasution, S. 1989. Berbagai Pendekatan Proses Belajar Mengajar. Jakarta: Bina Akasara.

Rohani, Ahmad. 1997. Media Instruksional Edukatif. Jakarta: Rineka Cipta.

Sudarsana, I. K. (2018). Pengaruh Model Pembelajaran Kooperatif Terhadap Peningkatan Mutu Hasil Belajar Siswa. Jurnal Penjaminan Mutu, 4(1), 20-31.

Sudirman, dkk. 1991. Ilmu Pendidikan. Bandung: Remaja Rosdakarya.

Sudjana, Nana, dkk. 1991. Media Pengajaran. Bandung: Sinar Baru.

Suryobroto. 2012. Proses Belajar Mengajar di Sekolah. Jakarta: Rineka Cipta.

Syaefuddin Saud, Udin. 2009. Pengembangan Profesi Guru. Bandung: Alfabeta.

Yao Tung, Khoe. 2015. Pembelajaran dan Perkembangan Belajar. Jakarta: Index 